\title{
Suïcide bij gedetineerden in België: een dossierstudie
}

\author{
Louis Favril, Ciska Wittouck, Kurt Audenaert \& Freya Vander Laenen
}

\section{Inleiding}

Wereldwijd vormt suïcide een belangrijke doodsoorzaak onder gedetineerden. ${ }^{1}$ Het suïcidecijfer (uitgedrukt in het aantal suïcides per 100.000 personen) in detentie ligt drie tot acht keer hoger ten opzichte van de vrije samenleving. ${ }^{2}$ De verklaring hiervoor is tweevoudig. ${ }^{3}$ Als groep vormen gedetineerden, nog voor hun opsluiting, een kwetsbare populatie. Risicofactoren voor suïcide die gelden in de algemene samenleving (zoals lage socio-economische status, impulsiviteit, psychiatrische stoornissen, middelenmisbruik en voorgaand suïcidaal gedrag) zijn disproportioneel aanwezig bij deze personen, en worden binnen de muren van de gevangenis geïmporteerd wanneer zij worden opgesloten. ${ }^{4}$ Daarenboven worden gedetineerden tijdens hun detentieperiode blootgesteld aan stressfactoren en ontberingen die eigen zijn aan de penitentiaire context. Voorbeelden hiervan zijn het verlies van vrijheid en autonomie, het wegvallen van steunfiguren, pesterijen, bedreigingen en geweld, overbevolking en het gebrek aan een zinvolle tijdsbesteding. Onderzoek toont aan dat deze voor detentie specifieke factoren het risico op suïcide tijdens de opsluiting aanzienlijk verhogen. ${ }^{5}$ Recent empirisch onderzoek ${ }^{6}$ bevestigt dat een dergelijk gecombineerd model - waarbij reeds kwetsbare personen worden blootgesteld aan een stressvolle context - een omvattende verklaring biedt voor het verhoogde suïciderisico bij gedetineerden, eerder dan énkel indivi-

1 K. Rabe, 'Prison structure, inmate mortality and suicide risk in Europe', International Journal of Law and Psychiatry 2012, 35, p. 222-230.

2 S. Fazel e.a., 'Prison suicide in 12 countries: an ecological study of 861 suicides during 2003-2007', Social Psychiatry and Psychiatric Epidemiology 2011, 46, p. 191-195.

3 L. Favril \& F. Vander Laenen, 'Suïcidaliteit in detentie: over kwetsbare personen in een stressvolle context', Fatik 2015, 148, p. 13-20.

4 S. Enggist e.a., Prisons and health, Genève: World Health Organization 2014; S. Fazel \& J. Baillargeon, 'The health of prisoners', Lancet 2011, 377, p. 956-965.

5 M.P. Huey \& T.L. McNulty, 'Institutional conditions and prison suicide: conditional effects of deprivation and overcrowding', Prison Journal 2005, 85, p. 490-514; M. Leese, S. Thomas \& L. Snow, 'An ecological study of factors associated with rates of self-inflicted death in prisons in England and Wales', International Journal of Law and Psychiatry 2006, 29, p. 355-360; G.E. Dear, Preventing suicide and other self-harm in prison, Houndmills: Palgrave Macmillan 2006.

6 L. Favril e.a., 'Suicidal ideation while incarcerated: prevalence and correlates in a large sample of male prisoners in Flanders, Belgium', International Journal of Law and Psychiatry 2017a, in druk; A. Rivlin e.a., 'Psychosocial characteristics and social networks of suicidal prisoners: towards a model of suicidal behaviour in detention', PLoS ONE 2013, p. 8-7. 
duele kwetsbaarheden of énkel situationele factoren. Een meta-analyse ${ }^{7}$ van 34 studies identificeerde enkele belangrijke risicofactoren voor suïcide in detentie, met name het alleen verblijven op cel, het statuut van de beklaagde, het veroordeeld zijn tot een levenslange gevangenisstraf, recente suïcidale gedachten, een geschiedenis van een suïcidepoging en psychiatrische diagnoses.

Cijfers omtrent, en achtergronden bij, suïcidaliteit in de Belgische gevangenissen zijn tot op heden vrij beperkt. Een recente studie ${ }^{8}$ met een representatieve steekproef van ruim 1.300 respondenten toont aan dat de prevalentie van suïcidale gedachten en suïcidepogingen over de levensloop respectievelijk $44,4 \%$ en $21,8 \%$ bedraagt bij gedetineerden in de Vlaamse gevangenissen. Wat betreft sterfgevallen door suïcide kan men zich in België enkel beroepen op de gegevens die worden gerapporteerd in de jaarverslagen van het directoraat generaal Penitentiaire Inrichtingen (DG EPI). Naast de absolute cijfers (het aantal suïcides per jaar) worden echter geen verdere details vrijgegeven, zoals over de verdeling naar geslacht, leeftijd en detentiestatus, noch over de omstandigheden waarin de suïcides plaatsvonden. Nochtans biedt dergelijke informatie een belangrijke grond voor suïcidepreventie in de gevangenissen. Zoals het National Institute for Health and Care Excellence recent aankaartte ${ }^{9}$ is het inderdaad noodzakelijk om factoren die verband houden met suïcide te identificeren wanneer men wetenschappelijk onderbouwde interventies wenst te ontwikkelen, met als doel suïcide(pogingen) bij gedetineerden te voorkomen. Het doel van de huidige studie was dan ook om, voor de eerste maal in België, een analyse uit te voeren van suïcides die in de Belgische gevangenissen plaatsvonden, teneinde handvatten aan te reiken voor suïcidepreventie. Hierbij werd zowel gekeken naar de achtergrondkenmerken van de gedetineerden die suïcide pleegden, alsook naar de kenmerken van de suïcides zelf.

\section{Methodologie}

\section{Inclusiecriteria}

We wensten alle suïcides te bestuderen die over een 17-jarige periode (2000-2016) plaatsvonden in de Belgische gevangenissen. Enkel sterfgevallen waarbij de doodsoorzaak (na een gerechtelijk onderzoek door een wetsgeneesheer) als suïcide werd geïdentificeerd, werden in de huidige studie geïncludeerd. Personen die administratief waren ingeschreven in een gevangenis, maar daar niet fysiek verbleven (bijvoorbeeld in het geval van elektronisch toezicht of penitentiair verlof), werden niet opgenomen in de huidige studie. Bij het hanteren van deze inclusiecriteria werden in totaal 262 suïcides geïdentificeerd.

7 S. Fazel e.a., 'Suicide in prisoners: a systematic review of risk factors', Journal of Clinical Psychiatry 2008, 69, p. 1721-1731.

8 L. Favril, F. Vander Laenen \& K. Audenaert, 'Suïcidaal gedrag bij gedetineerden in Vlaanderen: prevalentie en samenhang met psychische distress', Tijdschrift voor Psychiatrie 2017b, 59, p. 203-211.

9 NICE, Mental health of adults in contact with the criminal justice system, Londen: National Institute for Health and Care Excellence 2017. 


\section{Databronnen}

Een lijst van deze 262 personen die overleden door suïcide in de periode van 1 januari 2000 tot en met 31 december 2016 werd verkregen via DG EPI. Voor elk geval van suïcide (hierna: case) werd het detentiedossier bij de Directie Detentiebeheer van DG EPI (hierna: dossier) opgevraagd, hetgeen alle relevante informatie van de gedetineerde in kwestie verzamelt. Elk van deze dossiers werd vervolgens nauwkeurig bestudeerd. Op basis van de wetenschappelijke literatuur ${ }^{10}$ werd een checklist ontwikkeld om alle dossiers op een uniforme wijze te analyseren. De eerste 25 dossiers (9,5\%) werden door de twee eerstgenoemde auteurs (Favril en Wittouck) elk afzonderlijk geanalyseerd en nadien vergeleken teneinde de interbeoordelaarsbetrouwbaarheid te verhogen. Voor de resterende dossiers werden onduidelijkheden gescoord op basis van teamconsensus na overleg. Allemaal deel uitmakend van hun dossier betroffen de primaire bronnen voor elke case enerzijds de opsluitingsfiche en SIDIS Suite (de elektronische databank voor gegevens van gedetineerden in België) voor demografische en criminologische gegevens, en anderzijds het 'PV van zelfmoord' dat standaard wordt opgemaakt in het geval van een suïcide in detentie. In dit document worden de omstandigheden en de context van het incident volgens een sjabloon beschreven. Dertien PV's konden echter niet worden teruggevonden, waardoor deze cijfers betrekking hebben op 249 suïcides (95\%). Indien beschikbaar, werden tevens de verslagen die werden opgemaakt door de Psychosociale Dienst (PSD) van de gevangenis geanalyseerd.

\section{Ethische aspecten}

Het studieprotocol werd goedgekeurd door de ethische commissie van de Universiteit Gent, faculteit Recht en Criminologie. Toestemming voor de uitvoering van de studie werd verkregen via het DG EPI. De studie werd tevens geregistreerd bij de Commissie voor de Bescherming van de Persoonlijke Levenssfeer.

\section{Resultaten}

\section{Suïcidecijfers}

Op basis van de data verschaft door DG EPI overleden in totaal 794 gedetineerden in de Belgische gevangenissen tussen 2000 en 2016. Van deze overlijdens werden er 262 (33\%) als suïcide geclassificeerd, wat een gemiddelde van 15,4 suïcides per jaar reflecteert (zie tabel 1). Het jaarlijkse suïcidecijfer fluctueerde sterk: van 86,9 per 100.000 gedetineerden in 2004 tot 270,7 per 100.000 in 2001 (zie figuur 1). Over de 17-jarige studieperiode bedroeg het gemiddelde jaarlijkse suïcidecijfer in België 156,2 per 100.000 gedetineerden.

10 C. O’Driscoll, A. Samuels \& M. Zacka, 'Suicide in New South Wales prisons, 1995-2005: towards a better understanding', Australian and New Zealand Journal of Psychiatry 2007, 41, p. 519-524 (Appendix I). 
Figuur 1 Sücide en overlijdens door andere oorzaken in de Belgische gevangenissen, 2000-2016

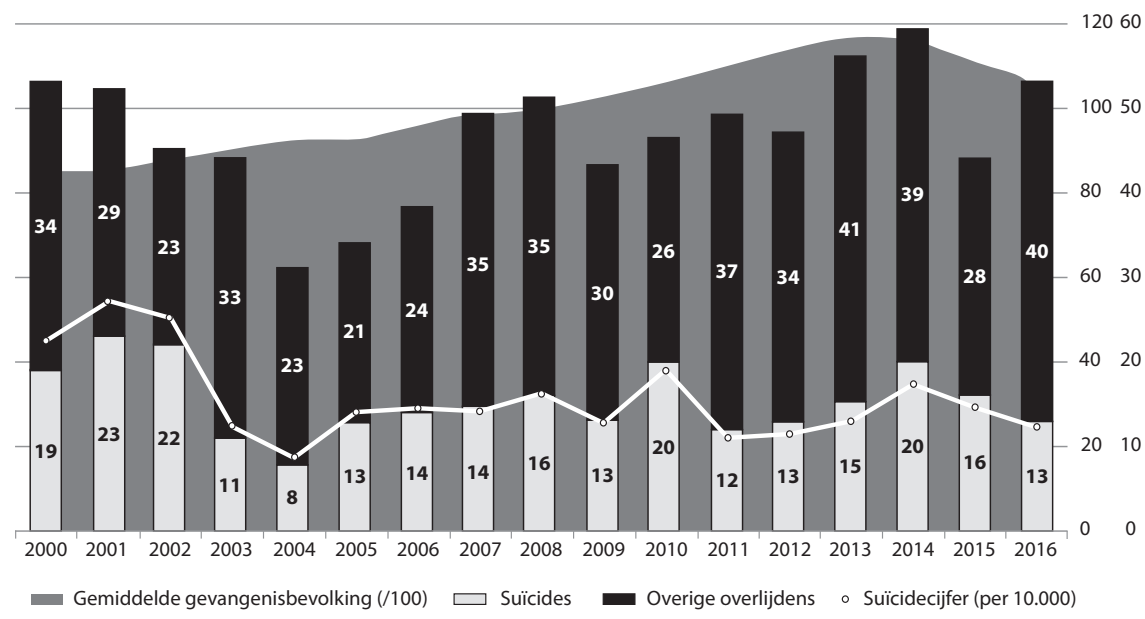

Demografische en criminologische kenmerken

Zoals beschreven in tabel 2 betrof 94,7\% ( $\mathrm{N}=248)$ van alle cases mannelijke gedetineerden. De gemiddelde leeftijd bedroeg 37 jaar (range: 19-78), en de modale leeftijdsklasse was 25-34 jaar (36,3\%). Qua nationaliteit was de overgrote meerderheid (77,5\%) Belg. Eén op vier was gehuwd bij overlijden (24,8\%). Wat betreft criminologische kenmerken waren op het moment van de suïcide 109 gedetineerden (41,6\%) beklaagd, vielen er 47 (17,9\%) onder het statuut van internering ${ }^{11}$ en waren 106 personen $(40,5 \%)$ veroordeeld tot een gevangenisstraf. Onafhankelijk van detentiestatus waren (poging tot) levensdelicten (moord of doodslag) voor een derde van de studiepopulatie (32,4\%) de reden tot opsluiting, gevolgd door vermogensdelicten met of zonder geweld (29\%) en seksuele delicten (16\%).

Wanneer het tijdsinterval tussen de opsluiting in de gevangenis en de suïcide werd onderzocht, tonen de resultaten aan dat 20 gedetineerden $(7,6 \%)$ suïcide pleegden binnen de 24 uur na opsluiting (zie tabel 3). Een vijfde (21,8\%) van alle suïcides vond plaats tijdens de eerste maand van de opsluiting, met $15,6 \%$ van alle cases binnen de eerste week. Voor de helft van alle suïcides tussen 2000-2016 bedroeg de detentieduur zes maanden of minder. De mediaan van de detentieduur tussen de initiële opsluiting en de suïcide bedroeg 171,5 dagen (wat overeenstemt met 5,6 maanden).

11 Internering is een strafrechtelijke maatregel in België voor personen met een psychiatrische problematiek die strafbare feiten hebben gepleegd en ontoerekeningsvatbaar zijn verklaard door een rechter (enigszins te vergelijken met de tbs-maatregel in Nederland). 
Tabel 1 Overlijdens ( $N=794)$ en suïcides $(N=262)$ in de Belgische gevangenissen, 2000-2016.

\begin{tabular}{|c|c|c|c|c|}
\hline Jaar & $\begin{array}{l}\text { Gemiddelde } \\
\text { bevolking }^{\text {a }}\end{array}$ & $\begin{array}{l}\text { Totaal aantal } \\
\text { overlijdens }^{\text {b }}\end{array}$ & $\begin{array}{l}\text { Aantal suïci- } \\
\text { des}^{c}(\% \text { overlij- } \\
\text { dens) }\end{array}$ & Suïcidecijfer ${ }^{d}$ \\
\hline 2000 & 8.464 & 53 & $19(35,8)$ & 224,5 \\
\hline 2001 & 8.497 & 52 & $23(44,2)$ & 270,7 \\
\hline 2002 & 8.769 & 45 & $22(48,9)$ & 250,9 \\
\hline 2003 & 9.008 & 44 & II $(25,0)$ & $122, \mid$ \\
\hline 2004 & 9.201 & 31 & $8(25,8)$ & 86,9 \\
\hline 2005 & 9.238 & 34 & $13(38,2)$ & 140,7 \\
\hline 2006 & 9.579 & 38 & $14(36,8)$ & 146,2 \\
\hline 2007 & 9.873 & 49 & $14(28,6)$ & $|4|, 8$ \\
\hline 2008 & 9.891 & 51 & $16(3 \mid, 4)$ & 161,8 \\
\hline 2009 & 10.238 & 43 & $13(30,2)$ & 127,0 \\
\hline 2010 & 10.536 & 46 & $20(43,5)$ & 189,8 \\
\hline 2011 & 10.974 & 49 & $12(24,5)$ & 109,4 \\
\hline 2012 & 11.330 & 47 & $13(27,7)$ & 114,7 \\
\hline 2013 & 11.645 & 56 & $15(26,8)$ & 128,8 \\
\hline 2014 & 11.578 & 59 & $20(33,9)$ & 172,7 \\
\hline 2015 & 11.041 & 44 & $16(36,4)$ & 144,9 \\
\hline 2016 & 10.619 & 53 & $13(24,5)$ & 122,4 \\
\hline Gemiddelde & 10.028 & 46,7 & $15,4(33,0)$ & 156,2 \\
\hline
\end{tabular}

${ }^{a}$ Gemiddelde gevangenisbevolking in het betreffende jaar (cijfergegevens DG EPI).

${ }^{b}$ Het totaal aantal overlijdens (inclusief suïcides) in detentie. Bron: jaarverslagen DG EPI (20062016); Vraag en Antwoord Belgische Senaat, 2007, Schriftelijke vraag nr. 3-5I83 door H. Vandenberghe (2000-2005).

${ }^{\mathrm{c}}$ Het aantal suïcides zoals geïdentificeerd in de huidige studie.

${ }^{d}$ Het aantal suïcides per 100.000 gedetineerden.

\section{Klinische factoren}

Van de gedetineerden waar klinische informatie beschikbaar was (zoals een PSDverslag), was bij $86,7 \%(\mathrm{~N}=156)$ sprake van een vastgestelde psychiatrische problematiek (zie tabel 4). Opgesplitst was bij de helft van alle cases (52,8\%) melding van een As I-psychopathologie (zoals depressie, schizofrenie of een angststoornis), bij een derde (36,7\%) van een middelengerelateerde problematiek (drugs, alcohol of andere middelen), en bij één op de acht $(13,9 \%)$ van een persoonlijkheidsstoornis. Bij de helft ( $\mathrm{N}=71 ; 50,4 \%$ ) van alle cases waar informatie beschikbaar was over voorgaand suïcidaal gedrag $(\mathrm{N}=141)$, was minstens één voorgaande suïcidepoging gekend - bij $17,7 \%$ buiten een periode van detentie, bij één op de drie (35,5\%) tijdens een opsluiting, en bij 2,8\% in beide gevallen. 
Tabel 2 Demografische en criminologische gegevens van alle suïcides, 2000$2016(N=262)$.

\begin{tabular}{lll}
\hline Variabele & Aantal & Percentage \\
\hline Geslacht: man & 248 & 94,7 \\
Leeftijd & & 11,8 \\
$18-24$ & 31 & 36,3 \\
$25-34$ & 95 & 30,2 \\
$35-44$ & 79 & 13,7 \\
$45-54$ & 36 & 6,1 \\
$55-64$ & 16 & 1,9 \\
$\geq 65$ & 5 & 77,5 \\
Nationaliteit: Belg & 203 & 24,8 \\
Burgerlijke status: gehuwd & 65 & \\
Detentiestatus & & 41,6 \\
Beklaagd & 109 & 40,5 \\
Veroordeeld & 106 & 17,9 \\
Geinterneerd & 47 & \\
Type misdrijf (primair) & & 16,0 \\
Seksueel delict & 42 & 32,4 \\
Levensdelict & 85 & 29,0 \\
Vermogensdelict & 76 & 11,1 \\
Drugsdelict & 29 & 11,5 \\
Ander delict & 30 & 47,5 \\
Voorgaande detentie(s) & 97 &
\end{tabular}

Omstandigheden van de suïcides

Uit tabel 5 blijkt dat de meerderheid van alle suïcides in detentie $(84,7 \%)$ plaatsvonden in de cel van de gedetineerde in kwestie; 151 (60,6\%) in gevallen waar de persoon alleen op cel verbleef, en 60 (24,1\%) wanneer sprake was van één of meer celgenoten. Wat betreft deze laatste groep was de celgenoot in $63,3 \%$ van de 60 gevallen afwezig op het moment van de suïcide (bijvoorbeeld omwille van bezoek, werk of wandeling), waardoor de gedetineerde de facto alleen verbleef op cel. Eén suïcide op de tien $(11,2 \%)$ vond plaats wanneer de gedetineerde in kwestie in een veiligheids- of strafcel verbleef. Negen suïcides $(3,6 \%)$ geschiedden in de gevangenis, maar buiten de cel (bijvoorbeeld in de wasruimte), en één suïcide $(0,4 \%)$ gebeurde buiten de muren van de gevangenis, meer bepaald in het Justitiepaleis waar de gedetineerde tijdelijk was overgebracht ter verschijning voor de Raadkamer. Aangaande de methode van suïcide werd, ongeacht de locatie, verhanging/ verstikking in de overgrote meerderheid van alle gevallen aangewend (90\%). Bij de overige suïcides $(\mathrm{N}=25)$ werd de methode van overdosis of zelfvergiftiging $(3,6 \%)$, snijden $(3,2 \%)$ en het springen van een hoogte $(2,8 \%)$ aangewend. 
Tabel 3 Tijdsinterval tussen de initiële opsluiting en suïcide $(N=262)$.

\begin{tabular}{llll}
\hline $\begin{array}{l}\text { Duur sinds } \\
\text { opsluiting }\end{array}$ & Aantal & Percentage & $\begin{array}{l}\text { Cumulatief } \\
\text { percentage }\end{array}$ \\
\hline$\leq 24$ uur & 20 & 7,6 & 7,6 \\
$>$ I dag - I week & 21 & 8,0 & 15,6 \\
$>$ I week - I maand & 16 & 6,1 & 21,8 \\
$>$ I-6 maanden & 76 & 29,0 & 50,8 \\
$>6-12$ maanden & 39 & 14,9 & 65,6 \\
$>1-5$ jaar & 67 & 25,6 & 91,2 \\
$>5$ jaar & 23 & 8,8 & 100 \\
\hline
\end{tabular}

Tabel 4 Beschikbare klinische gegevens van suïcides, 2000-2016.

\begin{tabular}{lll}
\hline Variabele & Aantal & Valide percentage $^{\mathrm{a}}$ \\
\hline $\begin{array}{l}\text { Psychiatrische problema- } \\
\text { tiek }^{\mathrm{b}}\end{array}$ & 156 & 86,7 \\
As I-psychopathologie & 95 & 52,8 \\
Middelengerelateerd & 66 & 36,7 \\
Persoonlijkheidsstoornis & 25 & 13,9 \\
Voorgaande suïcidepoging & 71 & 50,4 \\
Buiten detentie & 25 & 17,7 \\
Tijdens detentie & 50 & 35,5 \\
\hline
\end{tabular}

a Percentages berekend op basis van het aantal cases waar data beschikbaar voor was. ${ }^{\mathrm{b}}$ Data beschikbaar voor I $80(68,7 \%)$ van alle cases. ${ }^{c}$ Data beschikbaar voor I4I $(53,8 \%)$ van alle cases.

Algemeen waren de suïcides evenredig verspreid over de week (variërend van $13,7 \%$ tot $14,9 \%$ per dag) en over het jaar (op maandbasis lagen de cijfers gespreid tussen $6,5 \%$ en $10,3 \%$ ), en was er geen duidelijk patroon te observeren. Wat betreft timing tijdens de dag blijkt het merendeel van de suïcides (16,9\%) plaats te vinden tussen 15.01 en 18.00 uur, en het minste aantal suïcides werden geregistreerd tussen 06.01 en 09.00 uur $(6,4 \%)$. Samengenomen vonden 56 suïcides $(24,8 \%)$ plaats tussen 06.01-15.00 uur, terwijl 43,1\% zich voordeed tijdens de nachtshift van het penitentiair personeel (21.01-06.00 uur).

Op het moment van de suïcide was $41,8 \%$ van alle gedetineerden onderworpen aan een maatregel van verhoogd toezicht (zoals 'bijzondere bewaking'). Een dergelijke maatregel omvat een visuele controle van de gedetineerde, elke 15 of 30 minuten. Aangezien dit in het geval van plaatsing in een veiligheids- of strafcel standaard het geval is, werden deze tevens geïncludeerd ( $N=28$ of $11,2 \%$ van alle cases). De overige suïcides onder verhoogd toezicht $(N=76)$ betroffen gedetineerden die op hun reguliere cel verbleven in de algemene detentiepopulatie. Van alle cases $(\mathrm{N}=262)$ werden 24 gedetineerden $(9,2 \%)$ getransfereerd naar de gevangenis waar de suïcide plaatsvond binnen een maand voorafgaand aan de suïcide. Bij een vijfde van de totale studiepopulatie $(21,1 \%)$ was er binnen de range van vijf 
Tabel 5 Omstandigheden van suïcides, 2000-2016 (N=249).

\begin{tabular}{|c|c|c|}
\hline Variabele & Aantal $^{\mathrm{a}}$ & Valide percentage \\
\hline \multicolumn{3}{|l|}{ Methode } \\
\hline Verhanging/verstikking & 224 & 90,0 \\
\hline Snijden & 8 & 3,2 \\
\hline Springen van hoogte & 7 & 2,8 \\
\hline Zelfvergiftiging/overdosis & 9 & 3,6 \\
\hline Ander & 1 & 0,4 \\
\hline \multicolumn{3}{|l|}{ Timing } \\
\hline $00: 01-03: 00$ & 32 & 12,9 \\
\hline 03:0I - 06:00 & 37 & 14,9 \\
\hline $06: 01-09: 00$ & 16 & 6,4 \\
\hline $09: 01-12: 00$ & 24 & 9,6 \\
\hline$|2: 0|-\mid 5: 00$ & 22 & 8,8 \\
\hline$|5: 0|-18: 00$ & 42 & 16,9 \\
\hline$|8: 0|-21: 00$ & 38 & 15,3 \\
\hline $21: 01-24: 00$ & 38 & 15,3 \\
\hline Recente justitiële gebeurtenis & 53 & 21,1 \\
\hline \multicolumn{3}{|l|}{ Locatie } \\
\hline Monocel $^{b}$ & $15 \mid$ & 60,6 \\
\hline Meerpersoonscel & 60 & 24,1 \\
\hline Veiligheids-/strafcel & 28 & $\mathrm{II}, 2$ \\
\hline Buiten cel (in gevangenis) & 9 & 3,6 \\
\hline Buiten gevangenis & I & 0,4 \\
\hline Onder verhoogd toezichtc & 104 & 41,8 \\
\hline
\end{tabular}

a Dertien PV's konden echter niet worden teruggevonden, waardoor deze cijfers betrekking hebben op 249 suïcides (95\%).

b Het alleen verblijven op cel, niet per definitie in een éénpersoonscel.

c Betreft een speciaal regime (bijvoorbeeld bijzondere bewaking) waarbij de gedetineerde elke 15 of 30 minuten wordt geobserveerd in diens eigen cel, of het verblijf in een veiligheidscel (onafgezien de reden daartoe) waar per definitie verhoogd toezicht van toepassing is.

dagen voor of na de suïcide sprake van een significante justitiële gebeurtenis, zoals een (geplande) hoorzitting van de rechtbank, een beroepsprocedure, (de dreiging van) een effectieve veroordeling of de verdere handhaving van de voorlopige hechtenis door de Raadkamer.

\section{Discussie}

\section{Omvang van het probleem}

Jaarlijks overlijden gemiddeld 15,4 gedetineerden door suïcide in België; een derde van alle sterfgevallen binnen de gevangenismuren. Over de periode 2000 tot en met 2016 bedroeg het gemiddelde jaarlijkse suïcidecijfer in België 156,2 per 
100.000 gedetineerden. We observeerden vrij grote variaties in de suïcidecijfers, gaande van 86,9 (2004) tot 270,7 (2001) per 100.000 gedetineerden. Dergelijke fluctuaties zijn te wijten aan de (statistisch) kleine absolute aantallen van suïcides waarop deze suïcidecijfers zijn gebaseerd (range: 8-23), waardoor kleine schommelingen een grote impact kunnen hebben. Wanneer we vergelijken met de algemene Belgische bevolking (zie Appendix), kunnen we stellen dat het gemiddelde suïcidecijfer grofweg acht keer hoger ligt in detentie - een bevinding die overeenstemt met voorgaand internationaal onderzoek in twaalf landen. ${ }^{12}$ We kunnen dus stellen dat gedetineerden een hoog-risicogroep vormen voor suïcide, niet enkel in België maar ook wereldwijd.

\section{Het profiel van gedetineerden die suïcide plegen}

De analyse van alle gevallen van suïcide toont aan dat vooral ongehuwde mannen van rond de 37 jaar suïcide plegen in detentie. Met betrekking tot nationaliteit was $77 \%$ van alle gedetineerden in de onderzoeksgroep Belg, terwijl officiële statistieken van DG EPI aantonen dat zij grofweg $50 \%$ van de totale gedetineerdenpopulatie in België uitmaakten in de periode 2000-2016. Deze bevinding wordt bevestigd door Europees onderzoek, waar de grote meerderheid van alle gedetineerden die suïcide pleegden in detentie personen waren met de nationaliteit van het desbetreffende land. ${ }^{13}$

Bij twee op vijf suïcides (41,6\%) verbleef de persoon in voorlopige hechtenis. $\mathrm{Bij}$ de resterende $60 \%$ werd reeds een vonnis uitgesproken door een rechter: 40,5\% was veroordeeld en $17,9 \%$ was geïnterneerd. Hoewel een dergelijke verdeling naar detentiestatus ruwweg overeenstemt met de verdeling in de Belgische gevangenissen over de desbetreffende periode (33,6\% beklaagd, 56,5\% veroordeeld en $9,9 \%$ geïnterneerd), kunnen we stellen dat het aantal suïcides bij geïnterneerden duidelijk oververtegenwoordigd is ten opzichte van de totale gedetineerdenpopulatie van personen met het statuut van internering (17,9\% versus $9,9 \%$ ).

Onafhankelijk van detentiestatus betrof ongeveer de helft van alle suïcides $(48,4 \%)$ personen die verdacht werden van, of veroordeeld waren voor, (een poging tot) een levensdelict (doodslag of moord) of een seksueel misdrijf, terwijl deze misdrijven volgens de Raad van Europa ${ }^{14}$ 'slechts' $20 \%$ van de totale gevangenisbevolking vertegenwoordigen in België. Dit onevenredige aandeel van dergelijke misdrijven bij personen die suïcide plegen in detentie bevestigt eerder onderzoek, waar ernstige en gewelddadige delicten als een duidelijke risicofactor voor suïcide tijdens de detentie werden geïdentificeerd. ${ }^{15}$

12 Fazel e.a. 2011.

13 S. Gauthier, T. Reisch \& C. Bartsch, 'Swiss prison suicides between 2000 and 2010', Crisis 2015, 36, p. 110-116; D. Radeloff e.a., 'Male suicide rates in German prisons and the role of citizenship', PLoS ONE 2017, p. 12-16.

14 Annual Penal Statistics (SPACE I) van de Raad van Europa, jaarrapporten 2000-2015.

15 Fruehwald e.a., 'Suicide in custody: case-control study', British Journal of Psychiatry 2004, 185, p. 494-498; R.T. Webb e.a., 'Suicide risk among violent and sexual criminal offenders', Journal of Interpersonal Violence 2012, 27, p. 3405-3424. 


\section{Klinische kwetsbaarheden}

Op klinisch vlak toont de studie aan dat bij de helft van de gedetineerden die suïcide pleegden in de Belgische gevangenis $(50,4 \%)$ een voorgeschiedenis van één of meer suïcidepogingen vermeld werd in het dossier. Dit wordt bevestigd door een meta-analyse, ${ }^{16}$ waar bij de helft van alle gedetineerden die suïcide pleegden in detentie een voorgeschiedenis van een suïcidepoging was gekend, wat de kans op suïcide tijdens de detentie significant verhoogde. Voor gedetineerden waar informatie beschikbaar was omtrent de geestelijke gezondheid, bleek dat bij de grote meerderheid $(86,7 \%)$ een psychiatrische aandoening was gedocumenteerd. Ook deze bevinding ligt in lijn met voorgaand onderzoek in detentie, dat een psychiatrische problematiek als een duidelijke risicofactor voor suïcide identificeerde. ${ }^{17}$ Hoewel vorenstaande bevindingen kunnen worden vereenzelvigd met eerder internationaal onderzoek, ontbreekt echter een vergelijkingsbasis in de huidige studie. Voor de bestudeerde periode zijn namelijk geen cijfers voorhanden van suïcidepogingen en psychiatrische stoornissen in de algemene gedetineerdenpopulatie in België. Recent onderzoek bij een representatieve steekproef van 1.326 gedetineerden in Vlaamse gevangenissen toont echter wel aan dat de lifetime prevalentiecijfers voor suïcidepogingen ${ }^{18}$ (21,8\%) en psychiatrische diagno$\operatorname{ses}^{19}(46,3 \%)$ aanzienlijk lager liggen dan de cijfers die in de huidige studiepopulatie werden gevonden (respectievelijk 50,4\% en $86,7 \%$ ).

\section{Risicoperiodes tijdens de detentie}

De huidige studie toont aan dat de eerste fase van de detentie een risicoperiode voor suïcide vormt, wat in lijn ligt met eerder onderzoek. ${ }^{20}$ Een vijfde van alle suïcides $(21,8 \%)$ vond plaats binnen de eerste maand na aanvang van de detentie, met $15,6 \%$ binnen de eerste zeven dagen na aankomst in de gevangenis. De reden voor het feit dat de periode kort na opsluiting een hoog-risicoperiode vormt, kan met enige voorzichtigheid worden verklaard door de stressvolle aard van de initiele fase van detentie. De transitie van de vrije samenleving naar de gevangenis impliceert voor velen immers een abrupt verlies van vrijheid, autonomie en sociale ondersteuning, al dan niet gepaard met detoxificatieverschijnselen. ${ }^{21}$ Hierbij aansluitend wijzen de resultaten op het feit dat een transfer naar een andere gevangenis mogelijk een risicoperiode voor suïcide kan inhouden. Honderd personen van alle gedetineerden die suïcide pleegden in detentie kenden minstens één transfer, naar de gevangenis alwaar de suïcide plaatsvond, waarbij $24 \%$ van hen suïcide pleegde binnen een maand na de transfer ( $16 \%$ binnen zeven dagen). Een

17 Fazel e.a. 2008; Fruehwald e.a. 2004; A. Rivlin e.a., 'Psychiatric disorders in male prisoners who made near-lethal suicide attempts: case-control study', British Journal of Psychiatry 2010, 197, p. 313-319.

18 Favril e.a. 2017b.

19 L. Favril, F. Vander Laenen \& K. Audenaert, 'Psychiatrische morbiditeit bij gedetineerden in Vlaanderen', Panopticon 2017, 38, p. 231-245.

20 O’Driscoll, Samuels \& Zacka 2007; J. Shaw e.a., 'Suicide by prisoners: national clinical survey', British Journal of Psychiatry 2004, 184, p. 263-267.

21 WHO, Preventing suicide in jails and prisons, Genève: World Health Organization 2007. 
transfer (ten gevolge van een incident, een effectieve veroordeling of een andere ingrijpende gebeurtenis) kan opnieuw worden gezien als een eerste fase van detentie en dus als een risicoperiode voor suïcide. De huidige studie toont tevens aan dat belangrijke justitiële gebeurtenissen (zoals een veroordeling, hoorzitting of verschijning voor de Raadkamer), of zelfs de dreiging ervan, voor een vijfde van alle gedetineerden $(21,1 \%)$ plaatsvonden kort (vijf dagen) voor of na de suïcide. Deze gebeurtenissen kunnen extra stresserend zijn voor gedetineerden, en dient men dus als risicoperiodes op te vatten. ${ }^{22}$

\section{Tijdstip en celaccommodatie}

Een analyse van de tijdstippen van de suïcides in 2000-2016 toont een enigszins identificeerbaar patroon aan, waarbij $43,1 \%$ van alle suïcides plaatsvond tussen 21.01 en 06.00 uur. In deze uren is de personeelsbezetting in gevangenissen gewoonlijk lager, hetgeen dus verband zou kunnen houden met de kans op suïcide doordat sprake kan zijn van meer gevoelens van (sociaal) isolement, of doordat minder suïcides kunnen worden voorkomen op momenten dat er minder personeel aanwezig is. Andersom blijkt dat toch een groot aantal van de suïcides plaatsvindt gedurende de dag, wanneer in principe wel voldoende personeel aanwezig is. Andere factoren kunnen hiervoor dus verantwoordelijk zijn, zoals een interactie tussen de plaats van de suïcide en het tijdstip. In dit opzicht toont onderzoek ${ }^{23}$ aan dat suïcides bij gedetineerden die alleen verblijven op cel vaker plaatsvinden gedurende de nacht, terwijl diegenen die in een meerpersoonscel verblijven meer frequent overdag suïcide plegen, wanneer de medegedetineerden niet aanwezig zijn op cel omwille van bezoek, werk of wandeling. Uit een verdere analyse van onze data blijkt dat dit ook in België het geval is: $75,7 \%$ van alle suïcides 's nachts (tussen 21.01 en 06.00 uur) vond plaats in een cel waar de gedetineerde alleen verbleef. Afgezien van het tijdstip toonden verschillende studies reeds consistent aan dat het alleen verblijven op cel een duidelijke risicofactor vormt voor suïcide. ${ }^{24}$ Ten eerste kan een plaatsing in een individuele cel te wijten zijn aan specifieke eigenschappen van gedetineerden die er verblijven (zoals een psychische problematiek). Ten tweede gaat het gebrek aan een celgenoot gepaard met een verminderd sociaal contact en sociale controle, waardoor de suïcidale gedetineerde doorgaans voldoende tijd en privacy heeft om ongemoeid de suïcidale daad uit te voeren. Een mogelijke preventiestrategie is aldus het plaatsen van suïcidale gedetineerden op een cel waar een celgenoot aanwezig is. ${ }^{25}$ Uit de huidige resultaten blijkt echter dat in meer dan $60 \%$ van alle suïcides bij gedetineerden die op een meerpersoonscel verbleven, de celgenoot op dat moment niet aanwezig was. Dit illustreert dat deze strategie geenszins sluitend is en als individuele strategie met de nodige voorzichtigheid moet worden aangewend ter preventie van suïcide in detentie.

24 Fazel e.a. 2008; Fruehwald e.a. 2004; N. Humber e.a., 'A national case-control study of risk factors among prisoners in England and Wales', Social Psychiatry and Psychiatric Epidemiology 2013, 48, p. $1177-1185$. 


\section{Isolatie en verhoogd toezicht}

Het alleen verblijven op cel blijkt in het bijzonder het suïciderisico bij gedetineerden te verhogen indien dit isolatie van de algemene gedetineerdenpopulatie betreft. Opmerkelijk is dat in de huidige studie één op de tien suïcides plaatsvond in een veiligheids- of isolatiecel. Deze strategie wordt aangewend omwille van het beveiligingseffect op korte termijn, doordat dit de toegang tot suïcidemethodes kan beperken - hoewel $100 \%$ van alle suïcides in isolatie plaatsvond door middel van verhanging. Op basis van de huidige cijfers kunnen we natuurlijk niet besluiten hoeveel suïcides wel werden voorkomen door een plaatsing in een veiligheidscel (deze data zijn immers niet beschikbaar), al is één suïcide op de tien in zulkdanige gecontroleerde omstandigheden enigszins verontrustend. De reden daartoe wordt veelal verklaard uit het feit dat de plaatsing in een dergelijke cel zowel een fysieke als een sociale isolatie impliceert, en protectieve factoren (zoals sociaal contact en zinvolle activiteiten) voor suïcide sterk minimaliseert. Aldus kan isolatie, voor sommigen, net het suïciderisico verhogen. Het restrictieve regime en de condities van isolatie, sensorische deprivatie en constante opsluiting die eigen zijn aan een dergelijke afzondering worden immers als bijzonder aversief en stressvol ervaren. Onderzoek wijst dan ook consequent op de schadelijke effecten van deze maatregel voor de mentale gezondheid en het welzijn van de gedetineerden. ${ }^{26}$ Ook hier kan een plaatsing in een veiligheidscel - om welke reden dan ook - de kwetsbaarheid van de gedetineerde in kwestie reflecteren (qua suïcidaliteit of psychiatrische morbiditeit). Gevoelens van angst en depressie, die in verband worden gebracht met suïcidaliteit, worden in afzondering vaak nog extra versterkt (indien dit niet gepaard gaat met voldoende zorg), hetgeen het suïciderisico duidelijk verhoogt. ${ }^{27}$ Aldus dient het gebruik hiervan dan ook slechts als ultimum remedium te worden ingezet, voor een zo beperkt mogelijke periode, in aanwezigheid van voldoende mogelijkheden tot sociaal contact en (psychologische) ondersteuning, alsook zinvolle activiteiten of bezoek.

Zoals dit de standaardprocedure inhoudt bij personen die zich in een veiligheidsof isolatiecel bevinden, kunnen personen in de algemene gedetineerdenpopulatie (dus wanneer zij zich in hun reguliere cel bevinden) tevens onder verhoogd toezicht worden geplaatst, zoals 'bijzondere bewaking'. Dit houdt een visuele controle in, elke 15 of 30 minuten, en kan om een diversiteit aan redenen worden aangewend (zoals psychische decompensatie, risicoperiodes, kort na opsluiting of wanneer de gedetineerde als suïcidaal wordt geïdentificeerd). In de huidige studie waren twee op de vijf gedetineerden het onderwerp van een dergelijke maatregel op het moment dat de suïcide plaatsvond. Dit impliceert enerzijds dat een gedetineerde als kwetsbaar of zelfs suïcidaal werd geïdentificeerd in deze gevallen, maar anderzijds dat een verhoogd toezicht geen maatregel mag zijn die op zichzelf staat, 'geïsoleerd' van andere preventiestrategieën. Er werd reeds beargumenteerd

26 S. Grassian, 'Psychiatric effects of solitary confinement', Journal of Law \& Policy 2006, 22, p. 325-383; C. Haney, 'The social psychology of isolation: why solitary confinement is psychologically harmful', Prison Service Journal 2009, 181, p. 12-20.

27 R.L. Bonner, 'Stressful segregation housing and psychosocial vulnerability in prison suicide ideators', Suicide and Life-Threatening Behavior 2006, 36, p. 250-254. 
dat verhoogd toezicht en monitoring elke 15 of 30 minuten een vals gevoel van veiligheid bij het personeel met zich kunnen brengen, alsook dat dit al te vaak gebeurt in afwezigheid van voldoende sociaal contact tussen de gedetineerde in kwestie en het personeel. ${ }^{28}$ Louter toezicht van suïcidale gedetineerden volstaat niet. Een benadering van verhoogd toezicht zonder een vorm van emotionele, sociale of zelfs klinische ondersteuning kan door de gedetineerde worden gepercipieerd als controle, eerder dan zorg, wat het suïciderisico geenszins reduceert.

\section{Methode van suïcide}

Studies tonen aan dat tot $90 \%$ van alle suïcides in detentie plaatsvindt door middel van ophanging, wurging of verstikking, ${ }^{29}$ wat duidelijk wordt bevestigd door de huidige resultaten. Dit is begrijpelijk, gezien de restrictieve en gecontroleerde aard van detentie, wat de beschikbaarheid van andere methoden begrenst, zoals bijvoorbeeld vuurwapens. Daartegenover zijn de mogelijkheden tot verhanging vrij aanwezig in detentie. Hoewel het beperken van methoden voor suïcide in de algemene samenleving een erg effectieve preventiestrategie blijkt te $z i j n,{ }^{30}$ is dit geen sinecure binnen de muren van de gevangenis. Zoals reeds vermeld, waren 28 gedetineerden in staat suïcide te plegen wanneer zij zich in de gecontroleerde omgeving van een veiligheids- of isolatiecel bevonden - allen door middel van verhanging.

\section{Methodologische aandachtspunten}

De huidige resultaten dienen in het licht van enkele beperkingen te worden geïnterpreteerd. Ten eerste werden enkel overlijdens bestudeerd waarvan de doodsoorzaak expliciet als 'suïcide' werd geclassificeerd door DG EPI, wat mogelijks inaccuraat is. Het is namelijk plausibel dat suïcides niet als dusdanig werden erkend, gezien suïcidale intentie niet steeds eenduidig te achterhalen is op retrospectieve wijze. Onderzoek toont bijvoorbeeld aan dat suïcides door middel van verdovende middelen (in afwezigheid van een afscheidsbrief) vaak onjuist als een accidentele overdosis worden gecategoriseerd, in het bijzonder bij personen met een gekende voorgeschiedenis van drugsgebruik, ${ }^{31}$ wat een onderschatting van het aantal suïcides zou impliceren. Een tweede beperking van het onderzoek inherent verbonden aan de methodologie van een dossierstudie - houdt in dat niet meer kon worden onderzocht dan datgene wat in de dossiers werd geregistreerd. De onderzoekers waren namelijk volledig afhankelijk van de kwantiteit en kwaliteit van de gedocumenteerde gegevens. Alhoewel voor elke gedetineerde demografische en criminologische gegevens beschikbaar waren, bleek de onvolledigheid van relevante data in het bijzonder van toepassing te zijn voor klinische gegevens. Zo was een PSD-dossier niet steeds voorhanden, bij uitstek voor gedeti-

28 H.G. Sanchez, 'Suicide prevention in administrative segregation units: what is missing?', Journal of Correctional Health Care 2013, 19, p. 93-100.

29 Gauthier, Reisch \& Bartsch 2015; Shaw e.a. 2004.

30 D. Gunnell e.a., 'The epidemiology and prevention of suicide by hanging: a systematic review', International Journal of Epidemiology 2005, 34, p. 433-442.

31 M.O. Olsson e.a., 'Risk factors for unnatural death: fatal accidental intoxication, undetermined intent and suicide', Drug and Alcohol Dependence 2016, 162, p. 176-181. 
neerden die kort na de opsluiting suïcide pleegden. Hierdoor kon relevante informatie voor deze cases niet worden opgenomen in de analyse. Een andere beperking verbonden aan dossierstudies houdt in dat informatie omtrent de subjectieve detentiebeleving van gedetineerden over het algemeen afwezig is. Hierbij kan bijvoorbeeld worden gedacht aan relaties met het penitentiair personeel, de mate van (ervaren) sociale ondersteuning, slachtofferschap van pesterijen of geweld tijdens de detentie, een relatiebreuk en (andere oorzaken van) gevoelens van hopeloosheid of angst. Nochtans werd duidelijk aangetoond dat deze factoren sterk verklarend zijn voor het suïciderisico bij gedetineerden. ${ }^{32}$ Ten slotte was voor een groot deel van de onderzochte variabelen (zoals het alleen verblijven op cel, onder verhoogd toezicht staan, transfers of justitiële gebeurtenissen) geen vergelijkingsbasis voorhanden, waardoor onze resultaten louter descriptief zijn. Dit is een gevolg van het feit dat dergelijke cijfergegevens van de algemene gedetineerdenpopulatie marginaal worden gerapporteerd in België. Een suggestie voor verder onderzoek is dan ook de inclusie van een controlegroep, waarbij uitspraken aangaande risicofactoren kunnen worden gemaakt (wat niet mogelijk is wanneer uitsluitend de 'suïcidegroep' wordt onderzocht). Niettegenstaande voornoemde beperkingen heeft de huidige studie - de eerste in België - enkele belangrijke implicaties voor suïcidepreventie in detentie.

\section{Implicaties voor suïcidepreventie}

Hoewel binnen het Vlaams Actieplan Suïcidepreventie (2012-2020) gedetineerden als een kwetsbare groep worden geïdentificeerd, blijft een uniform en uitgewerkt suïcidepreventiebeleid op nationaal niveau tot op heden uit in de Belgische gevangenissen. Nochtans leert onderzoek dat een dergelijk preventiebeleid het vóórkomen van suïcide in detentie aanzienlijk kan beperken. ${ }^{33}$ Zoals dit reeds van toepassing is in Nederland, ${ }^{34}$ is een uitgeschreven draaiboek in staat praktische handvatten aan te reiken voor de noodzakelijke multidisciplinaire benadering van suïcidaliteit bij gedetineerden. Hierbij is het echter van primordiaal belang dat, op basis van dergelijke (nationale) richtlijnen, een lokaal beleid wordt uitgebouwd, toegesneden op maat van de specifieke gevangenis. Immers, geen enkele (Belgische) penitentiaire inrichting is dezelfde, noch qua infrastructuur, noch qua gevangeniscultuur, noch qua gedetineerdenpopulatie. ${ }^{35}$

\section{Restrictieve preventie in combinatie met psychosociale interventies}

Een overkoepelende conclusie die we op basis van de huidige bevindingen kunnen maken is dat suïcidepreventie in detentie niet exclusief gericht mag zijn op restrictieve strategieën en het (fysiek) inperken van mogelijkheden voor suïcide.

32 Favril e.a. 2017a; Marzano e.a. 2016; Rivlin e.a. 2013.

33 E. Barker, K. Kolves \& D. De Leo, 'Management of suicidal and self-harming behaviors in prisons', Archives of Suicide Research 2014, 18, p. 227-240; Marzano e.a. 2016.

34 J.A. Westendorp e.a., Handreiking multidisciplinaire diagnostiek en behandeling suïcidaal gedrag in detentie voor zorgprofessionals binnen DJI, Amsterdam: Dienst Justitiële Inrichtingen 2016.

Favril \& Vander Laenen 2015. 
Gedetineerden kunnen deze restrictieve maatregelen, zoals verhoogd toezicht of de plaatsing in een veiligheidscel, als onaangenaam en zelfs als punitief ervaren vanwege hun depriverende aard. Bijgevolg kunnen (kan vrees voor) dergelijke maatregelen ervoor zorgen dat personen niet snel zullen aangeven wanneer men suïcidaal is. Aldus wordt hulpzoekend gedrag bij (suïcidale) gedetineerden ontmoedigd - wat in de algemene populatie, ${ }^{36}$ en meer specifiek in België, ${ }^{37}$ an sich al gepaard gaat met een veelheid aan barrières (bijvoorbeeld stigma). Onderzoek van Nederlandse bodem ${ }^{38}$ vond bijvoorbeeld dat veel gedetineerden zich beperkt voelden om suïcidale gedachten en gevoelens te bespreken met het personeel, uit vrees voor negatieve gevolgen zoals extra controlemaatregelen, de plaatsing in een andere cel of het verlies van privileges. Ook Amerikaans onderzoek ${ }^{39}$ beves- $^{-}$ tigde dat gedetineerden suïcidale gedachten ontkennen vanwege de angst om onder een speciaal regime te worden geplaatst. Omwille van deze redenen is het voor het bewakingspersoneel (extra) moeilijk om risicogedetineerden te identificeren en aldus in te grijpen in een vroeg stadium van het suïcidaal proces (alvorens een suïcidepoging wordt ondernomen). In dit opzicht dient het belang van de dynamische veiligheid te worden benadrukt. ${ }^{40}$ Immers, vanuit een goede verstandhouding en kwaliteitsvolle contacten en relaties met het bewakingspersoneel zullen de gedetineerden sneller geneigd zijn toenadering te zoeken tot het personeel, alsook om suïcidaliteit naar hen te communiceren. ${ }^{41}$ Zodoende kan suïcidaliteit in een vroege fase worden onderkend, waardoor niet meteen zou moeten worden overgegaan tot ingrijpende (restrictieve) interventies.

Naast restrictieve preventieve maatregelen die gericht zijn op de fysieke preventie van suïcidaal gedrag, moet evenzeer aandacht worden besteed aan de psychosociale voedingsbodem van de suïcidale problematiek. Of zoals Alison Liebling ${ }^{42}$ het formuleerde: 'Identifying vulnerability does not comprise a solution in itself, any more than isolation in stripped conditions addresses the problem of suicidal feelings.' De fysieke beperking van suïcidaal gedrag kan enkel nuttig zijn indien dit gecombineerd wordt met de reductie van het suïciderisico, bijvoorbeeld door middel van psychosociale interventies, ${ }^{43}$ geestelijke gezondheidszorg ${ }^{44}$ of sociale

36 M.A. Hom, I.H. Stanley \& T.E. Joiner, 'Evaluating factors and interventions that influence helpseeking and mental health service utilization among suicidal individuals: a review of the literature', Clinical Psychology Review 2015, 40, p. 28-39.

37 A. Reynders, Understanding differences between regional suicide rates, Leuven: LUCAS 2015.

38 A.J.F.M. Kerkhof \& W. Bernasco, 'Suicidal behavior in jails and prisons in the Netherlands: incidence, characteristics, and prevention', Suicide and Life-Threatening Behavior 1990, 20, p. 123-137.

39 B.B. Way e.a., 'Suicidal ideation among inmate-patients in state prison: prevalence, reluctance to report, and treatment preferences', Behavioral Sciences and the Law 2013, 31, p. 230-238.

40 H. Tournel, De gevangenisbewaarder: het professioneel leven in beeld, Antwerpen: Maklu 2014.

41 A. Ludlow e.a., Self-inflicted deaths in NOMS' custody amongst 18-24 year olds, Cambridge: RAND Europe 2015.

42 A. Liebling, Suicides in prison, Londen: Routledge 1992, p. 238.

43 D. Pratt, The prevention of suicide in prison, New York: Routledge 2016.

44 Marzano e.a. 2016; G.M. Winters, E. Greene-Colozzi \& E.L. Jeglic, 'Preventing suicide in forensic settings: assessment and intervention for inmates with serious mental illness', Journal of Correctional Health Care 2017, 23, p. 383-397. 
ondersteuning door het personeel ${ }^{45}$ of door medegedetineerden via peer support initiatieven. ${ }^{46}$ Gedetineerden die in een (aanhoudende) suïcidale crisis verkeren, zullen vroeg of laat een manier vinden om over te gaan tot suïcide indien gevoelens van wanhoop en hopeloosheid niet worden geadresseerd. In deze context tonen kwalitatieve studies ${ }^{47}$ duidelijk aan dat suïcidale gedetineerden vooral de behoefte uiten om over hun problemen te praten, gehoord te worden en emotionele ondersteuning te krijgen.

\section{Bewakingspersoneel als de hoeksteen voor suïcidepreventie}

Binnen de context van een multidisciplinair gedragen beleid vormt het penitentiair bewakingspersoneel de hoeksteen van suïcidepreventie binnen de muren van de gevangenis. ${ }^{48}$ Als eerstelijnsactoren dienen zij alert te zijn voor de vroegtijdige herkenning van (non-)verbale signalen van suïcidaliteit, wat begint bij een opleiding die hier voldoende aandacht aan besteedt en idealiter op herhaalde tijdstippen wordt opgefrist. Een adequate basistraining en vormingscontinuïteit voor het personeel wordt inderdaad als een sleutelcomponent voor suïcidepreventie erkend door de Wereldgezondheidsorganisatie. ${ }^{49}$ Dit kan immers de kennis, het vertrouwen en de attitudes omtrent suïcidaliteit verbeteren bij het personeel. Zoals eerder beschreven, ${ }^{50}$ is het in deze context essentieel dat een suïcidepreventiebeleid zowel centraal als lokaal wordt gedragen, waarbij een actieve ondersteuning van het uitvoerend personeel noodzakelijk is. Naast kwaliteitsvolle vormings- en opleidingsmogelijkheden dient eveneens tijd vrijgemaakt te worden voor het personeel om de deelname aan activiteiten die kaderen binnen suïcidepreventie mogelijk te maken.

\section{Conclusie}

In deze dossierstudie werden alle (geregistreerde) suïcides geanalyseerd die plaatsvonden in de Belgische gevangenissen over de periode 2000-2016. Gedurende de onderzoeksperiode overleden 262 gedetineerden door suïcide in detentie - een derde van alle sterfgevallen die in dit tijdsbestek werden gedocumenteerd. Dit stemt overeen met 156,2 suïcides per 100.000 gedetineerden, wat acht keer hoger is dan het suïcidecijfer in de algemene bevolking in België. Niettegenstaande deze hoge suïcidecijfers is er vooralsnog geen sprake van een uniform en geïntegreerd suïcidepreventiebeleid in de Belgische gevangenissen. Een dergelijk nationaal beleid binnen de gevangenismuren is niet enkel essentieel om de incidentie van suïcidaal gedrag te reduceren, maar kadert tevens binnen de context

Ludlow e.a. 2015.

B. Hall \& P. Gabor, 'Peer suicide prevention in a prison', Crisis 2004, 25, p. 19-26.

S. Berglund, S. Astrom \& B.M. Lindgren, 'Patients' experiences after attempted suicide: a literature review', Issues in Mental Health Nursing 2016, 37, p. 715-726; Marzano e.a. 2016.

8 Howard League, Preventing prison suicide: staff perspectives, Londen: The Howard League for Penal Reform 2017; Ludlow e.a. 2015.

WHO 2007.

H. van Laake \& R. van den Ameele, 'Reflecties inzake suïcidepreventie in een detentiecontext', Panopticon 2012, 33, p. 582-586. 
van een veilige en humane uitvoering van de vrijheidsberovende straf in België. Idealiter richten preventiemaatregelen zich niet exclusief op vormen van restrictieve preventie, maar omvatten evenzeer (psycho)sociale interventies die zich focussen op de grond van de suïcidale problematiek bij personen die (tijdelijk) in de gevangenis zijn opgesloten. Gezien de blijvende besparingen bij justitie, de aanhoudende overbevolking en de daaruit volgende stijgende werkdruk voor het personeel, vormt de preventie van suïcide bij gedetineerden in België echter geen (uitgesproken) beleidsmatige prioriteit. Deze realiteit in acht genomen, beklemtonen de auteurs toch dat (meer) aandacht voor suïcidepreventie een noodzakelijke voorwaarde is om de incidentie van suïcidaal gedrag in te perken. Hoewel niet alle suïcides in detentie kunnen worden voorkomen, kan enkel een geïntegreerde aanpak het aantal suïcides - en het leed dat deze veroorzaken bij nabestaanden, medegedetineerden en het gevangenispersoneel - reduceren.

APPENDIX. Suïcidecijfers in de algemene Belgische bevolking en in detentie, 2000-2014.

\begin{tabular}{|c|c|c|c|}
\hline \multirow[t]{2}{*}{ Jaar } & \multicolumn{2}{|c|}{ Suïcidecijfer (per 100.000) } & \multirow[t]{2}{*}{ Ratio $^{b}$} \\
\hline & $\begin{array}{l}\text { Belgische bevol- } \\
\text { king }^{\text {a }}\end{array}$ & Detentie & \\
\hline 2000 & 20,9 & 224,5 & 10,7 \\
\hline 2001 & 21,1 & 270,7 & 12,8 \\
\hline 2002 & 20,1 & 250,9 & 12,5 \\
\hline 2003 & 19,8 & $122, \mid$ & 6,2 \\
\hline 2004 & 19,1 & 86,9 & 4,5 \\
\hline 2005 & 19,4 & 140,7 & 7,2 \\
\hline 2006 & 18,4 & 146,2 & 7,9 \\
\hline 2007 & 17,5 & $|4|, 8$ & 8,1 \\
\hline 2008 & 18,7 & 161,8 & 8,6 \\
\hline 2009 & 18,7 & 127,0 & 6,8 \\
\hline 2010 & 18,5 & 189,8 & 10,3 \\
\hline 2011 & 19,0 & 109,4 & 5,7 \\
\hline 2012 & 18,3 & $1 \mid 4,7$ & 6,3 \\
\hline 2013 & $17, \mid$ & 128,8 & 7,6 \\
\hline 2014 & 17,0 & 172,7 & 10,2 \\
\hline Gemiddelde & 18,9 & 159,2 & 8,4 \\
\hline
\end{tabular}

${ }^{a}$ Berekend op basis van de totale Belgische bevolking gemeten op I januari van het betreffende jaar en het aantal suïcides in België in datzelfde jaar (bron: FOD Economie; http://statbel.fgov. be). Voor de jaren 2015 en 2016 waren de data (nog) niet beschikbaar, waardoor het suïcidecijfer niet berekend kon worden.

${ }^{b}$ Verhouding tussen de suïcidecijfers in detentie ten opzichte van de algemene Belgische bevolking (zie Fazel e.a. 20I I). 